\title{
ORTEGA Y GASSET E A VIDA AUTÊNTICA
}

\author{
ORTEGA Y GASSET AND REAL LIFE
}

\author{
José MAURICIO DE CARVALHO \\ Universidade Federal de são João del-Rei \\ josemauriciodecarvalho@gmail.com
}

RECIBIDO: 25 DE NOVIEMBRE DE 2013

ACEPTADO: 20 DE ENERO DE 2014

\begin{abstract}
Resumo: Nessa comunicação examinamos o que significa vida autêntica, o que é o mesmo que tratar de vida verdadeiramente humana. Para Ortega, uma vida assim é a que se vive na fidelidade a um núcleo íntimo insubornável e na superação de problemas da cultura que, em cada tempo, tem contornos próprios.
\end{abstract}

Palavras-chave: vida, autenticidad, fenomenologia, filosofia, Ortega y Gasset.

\begin{abstract}
The aim of this communication is to examine what's the meaning of an authentic life, which is the same of deal with a truly human life. For Ortega, a life is what we live in fidelity with a core intimate and incorruptible in overcoming problems of culture; in the same time, he expresses the risks of a mass society.
\end{abstract}

Keywords: Life, Authenticity, Phenomenology, Philosophy, Ortega y Gasset

\section{Considerações iniciais}

Autenticidade entra na agenda filosófica pela tradição fenomenológica. Um dos notáveis representantes da fenomenologia existencial, o alemão Karl Jaspers trata por autêntico o que é próprio do homem, em contraposição ao modo de vida inautêntico que não representa seu modo de ser.

Diante dos desafios de viver de modo singularmente humano pode-se perguntar se a meditação filosófica consegue dar uma palavra de orientação. Pode a Filosofia salvar o homem de suas atribulações rotineiras e de uma vida sem sentido meditado? Há uma forma de viver capaz de significar dores, sofrimentos e dramas da existência? Até que ponto uma consciência limitada pelas crenças pode apontar um caminho de vida autêntica? Vamos mostrar que apesar das limitações da razão, Ortega y Gasset considera que ela possa oferecer pistas para uma existência autêntica.

Desde 1923 quando Ortega publica El tema de nuestro tiempo parece que a sociedade ocidental valoriza essencialmente a razão, mas não se ocupa da sustentabilidade vital. Mais tarde, depois de 1930, quando ele inicia suas 
reflexões sobre o sentido histórico da razão sustentabilidade vital será substituído por crença. E o que defende Ortega naqueles dias? Ele diz que se o homem vive na insegurança de uma racionalidade limitada ele necessita de pontos de apoio, como o náufrago, explica em bela metafóra. É assim, como quem se afoga, que o homem procura apoios para ter uma vida boa.

Nessa comunicação vamos acompanhar Ortega y Gasset procurando os pontos de apoio na fidelidade a um núcleo íntimo, isto é, ao que somos, cada qual, na intimidade. Mostraremos também que essa procura precisa vencer as dificuldades de cada tempo histórico. Naqueles dias lhe parece que uma sociedade de massas produziu um homem incapaz de viver uma existência verdadeiramente humana.

\section{Vida autêntica e tradição fenomenológica}

Adotar um sentido de si mesmo é adotar uma existência autêntica, ou melhor, atingir um veio íntimo e profundo. Inautenticidade é, em contrapartida, a possibilidade do homem distanciar-se deste ponto abissal, afastar-se de si mesmo, perder-se no momentâneo, na imitação, no projeto de outrem. É o que dizia Karl Jaspers em Psicologia de las concepciones del mundo: "Lo auténtico es más profundo, en contraposición a lo superficial, es decir, es toda la existencia anímica penetrando frente a lo que passa com rapidez, es lo que sigue actuando frente a lo momentáneo; lo formado, lo dessarrolado, frente a lo adaptado, a lo imitado" .

$\mathrm{O}$ que o filósofo quer dizer é que o homem tem um impulso profundo que o estimula a se mover na existência. Agir conscientemente é mais vantajoso já que permite certo controle desse impulso vital, que sem ele levaria para lugares perigosos. Para orientar o sujeito contribuem as referências culturais que representam, ainda para Jaspers, a abertura à transcendência concebida pela Filosofia desde suas origens gregas. Ser consciente dessas referências significa orientar o impulso vital, pois quando perde o significado da transcendência, quando não vive o simbolismo o homem "fica à mercê (...) da cupidez e do tédio, da angústia e da indiferença"².

Avalia ainda Karl Jaspers que a inautenticidade é alimentada pela inconsciência provocada pela falta de meditação e esquecimento de si. O problema nasce de uma vida dedicada a trabalhos esgotantes, com pouca meditação e formação cultural insuficiente, vida limitada na repetição do

\footnotetext{
${ }^{1}$ JASPERS, Karl. Psicologia de las concepciones del mundo, Gredos, Madrid , 1967, p. 61.

2 JASPERS, Karl. Iniciação Filosófica, Guimarães, Lisboa, 1987, p. 109.
} 
trabalho rotineiro e sem sentido próprio. Dito de modo simples: uma vida inconsciente de si, perdida na rotina, que afasta o homem de suas melhores possibilidades, tornando-o não só perdido na vida, mas consumido por dores existenciais. Jaspers as examinou nos escritos psicológicos.

As reflexões de Karl Jaspers mostram que a inautenticidade e falta de sentido possuem implicações práticas, promovem dor e desorientação na alma (psiqué) humana. Esse foi o tema nuclear de outro psiquiatra e fenomenólogo conhecido. Victor Frankl explicou em A questão do sentido em psicoterapia que a perda de sentido torna a vida inautêntica, tira o desejo de viver e possui comprovado impacto psicológico. Eis como o disse: "Não foi menos importante a lição que eu pude levar para casa de Auschwitz e Dachau: que os mais capazes, inclusive de sobreviver a tais situações-limite eram os direcionados para o futuro, para algo ou alguém que os esperava. E uma série de psiquiatras confirmaram isso mais tarde no caso de prisioneiros de guerra nos acampamentos japoneses, nortecoreanos e norte vietnamitas ${ }^{3}$.

O que esses filósofos-psiquiatras mostraram é que quando o impulso vital se esgota na rotina, quando perde um sentido profundo, quando se limita à sobrevivência produz existência inautêntica e o fato tem implicações psicológicas negativas. No entanto, o cerne da questão é filosófica como indicou precisamente Martin Heidegger no parágrafo 9 de El ser y el tiempo ao afirmar que: "a analítica existenciaria del ser ahí, puede acotarse aún de una manera más rigurosa el tema del la analítica" ${ }^{4}$. A vida autêntica explicou Heidegger, vivida na intimidade do pensamento e no reconhecimento da angústia, não é transtorno psiquiátrico, mas o que supera a fala sem sentido e o afastamento do homem de si mesmo. E a inautenticidade é o contrário, ele explica no texto abaixo: "Y por ser en cada caso el ser ahi esencialmente su posibilidad, puede este ente en su ser elegirse a si mismo, ganarse, y también perderse, o no ganarse nunca, o sólo parece ser que se gana. Haberse perdido y aún no haberse ganado sólo lo puede en tanto es, por su esencia misma, posible ser ahi proprio, es decir, apropriado por sí mismo y para si mismo ${ }^{5}$.

Heidegger como Jaspers considera que permanecer nas ocupações quotidianas, sem cuidar do que singulariza a existência é uma forma de vida inautêntica. Trata-se, segundo ele, de uma possibilidade que o homem possui. De modo mais incisivo, Karl Jaspers e Victor Frankl apontam a primeira alternativa não só como possibilidade, mas como o que é preferível buscar e a inautenticidade como um perder-se de si mesmo a ser evitado.

\footnotetext{
${ }^{3}$ FRANKL, Victor. A questão do sentido em psicoterapia, Papirus, Campinas, 1990, p. 34.

${ }^{4}$ HEIDEGGER, Martin. El ser y el tiempo. 2. ed., Fondo de cultura económica, México, 1962, p. 57.

${ }^{5}$ Ibidem, p. 54.
} 
Num sentido semelhante ao proposto por esses fenomenólogos, Ortega y Gasset trata a vida autêntica como desafio do homem ${ }^{6}$. É das posições de Ortega y Gasset que falaremos, a seguir.

\section{Ortega y Gasset: Autenticidade como empenho de fidelidade a si}

O problema da autenticidade aparece nas reflexões de Ortega y Gasset em torno a dois núcleos temáticos. O primeiro consiste numa espécie de fidelidade íntima às crenças e ao projeto vital que norteia a vida singular de cada homem. Ortega y Gasset o expressa do seguinte modo em Ensimismamiento y Alteración: "La posibilidad de meditar, de recogerse dentro de sí mismo para ponerse consigo mismo de acuerdo y precisasse qui es lo que cree y qué es lo que no cree, lo que de verdad estima y lo que de verdad detesta. La alteración le obnubila, le ciega, le obliga a actuar mecanicamente en um frenético sonambulismo ${ }^{7}$.

A citação considera que o homem está desafiado a viver atento à suas exigências íntimas o que corresponde à necessidade, como também dizia Karl Jaspers, de superar o auto-esquecimento, de não negligenciar os riscos do esquecimento de si mesmo pela incorporação de hábitos, irrefletidas trivialidades e rotinas fixas.

Ortega y Gasset considera este estar em si como aspecto essencial da vida humana, agir conscientemente para se manter fiel a si mesmo, não se confundir quanto ao que acredita importante, mas ao contrário jogar luzes nas crenças, não se afastar de seu projeto, mas resignificá-lo, aprofundá-lo, melhorá-lo, redefini-lo se for necessário. O homem só fica seguro de si quando é fiel a sua vocação. Contra as tentativas de ser o que não se é, esclarece o filósofo na segunda parte de España Invertebrada, na fórmula de Pindaro: "Volvamos la espalda a las éticas mágicas e quedémonos com la única aceptable, que hace veintiséis siglos resumió Píndaro en su ilustre imperativo llega a ser lo que eres" ${ }^{\prime 8}$.

\footnotetext{
${ }^{6}$ Atualmente parece bem estabelecido que Ortega y Gasset, mesmo tendo se posicionado como crítico da fenomenologia no Prólogo para alemanes (1934) e em La idea de princípio en Leibniz (1940), é uma espécie de fenomenólogo, como explica Juan San Martin Sala em Ortega como fenomenólogo. Ali conclui sua exposição como se segue: "Una cosa queda clara, que Ortega supo reconocer en pocas publicaciones de Husserl un estilo de pensamiento que él assume y aplica, aunque no terminaba de entender, porque tampoco era tan fácil, con los escasos textos disponibles, ver cómo ese estilo se fundamentaba en las propuestas metodológicas de Husserl" (p. 41).

7 ORTEGA Y GASSET, José. Ensimismamiento y Alteración. Obras Completas. v. V, 2. reimpresión, Alianza, Madrid, 1994, p. 299.

${ }^{8}$ ORTEGA Y GASSET, José. España Invertebrada. Obras Completas. v. III, Alianza, Madrid. 1994, p. 102.
} 
A citação indica que a vida de cada homem segue um projeto vital, mas que o homem pode se perder dele, distanciar-se do que o projeto deveria antecipar. É o que lhe parece haver ocorrido com o poeta alemão Goethe. Na análise da sua vida, elaborada em Goethe desde dentro, afirma que ao negligenciar sua vocação Goethe se mostrou cheio de (1994): "dolor, de angustia, de enojo, de mal humor, de vacío"". Dar curso ao núcleo íntimo significa realizar a própria vocação e descobrir a felicidade. A vocação é o modo verdadeiro de realizar o projeto vital. A vocação aponta a direção a seguir. É ela que decide como levar adiante o projeto, mesmo que ela não se confunda com ele, conforme esclarece o filósofo no livro En torno a Galileo: "puedes ser lo que quieras, pero sólo si quieres ser de tal determinado modo serás el que tienes que ser. Es decir, que cada hombre, entre sus varios seres posibles encuentra siempre uno que es su auténtico ser. Y la voz que le llama a ese auténtico ser es lo que llamamos vocación"10.

$\mathrm{O}$ animal não vive essa possibilidade, ele não tem como chegar ao núcleo íntimo, pois está vive distanciado ou alienado de si, olhando para fora, respondendo ao entorno e a seus perigos. Eis como o filósofo descreve a vida animal em Ensimismamiento y Alteración: "Él no rige su existencia, no vive desde si mismo, sino que está siempre atento a lo que pasa fuera de él, a la otro que él. Nuestro vocablo otro es sino el latino alter. Decir, pues, que el animal no vive desde si mismo sino desde lo otro, traído y llevado y tiranizado por lo otro, equivale a decir que el animal vive siempre alterado, enajenado, que su vida es constitutiva alteración ${ }^{11}$.

O mergulhar do homem em seu íntimo é o que Martin Heidegger considerava raiz da autenticidade. Ortega y Gasset destaca que esse mergulho íntimo não acontece sem empenho e esforço, ainda que seja mesmo possibilidade humana. Esse é um aspecto importante de sua interpretação. O mergulho íntimo, a autodescoberta, a consciência de si, a elucidação das crenças e projetos resulta de esforço ou empenho pessoal e não é dádiva da natureza. Na raiz da questão ontológica encontra-se, portanto, uma motivação ética ampla assim proposta por Luís de Araújo no comentário que elaborou sobre a filosofia orteguiana no livro Sentido existencial da Filosofia:

Importa ter presente que há que intercorrelacionar aquele imperativo ético originário como Arturo Gaede designa vocação, com a dimensão material dos valores que lhes dá o

\footnotetext{
${ }^{9}$ ORTEGA Y GASSET, José. Goethe desde dentro. Obras Completas. v. IV, Alianza, Madrid, 1994, p. 407.

${ }^{10}$ ORTEGA Y GASSET, José. En torno a Galileo. Obras Completas. v. V, Alianza, Madrid, 1994, p. 138.

${ }_{11}$ ORTEGA Y GASSET, José. Ensimismamiento y Alteración. Obras Completas. v. V, Alianza, Madrid, 1994, p. 299.
} 
tom de dignidade ou de indignidade, a fim de divisar o perfil de uma vida autêntica no profundo sentido ético do termo autenticidade, quanto a nós, como algo resultante não do elementar plano da sensibilidade individual, sempre determinada pelos seus estados efêmeros do prazer e da dor, mas sim de um empenhamento sincero, exigente e atento da personalidade, isto é, da unidade temperamento-caráter de cada ser humano ${ }^{12}$

É o mesmo o que afirma Ortega y Gasset no texto que se segue, uma vida autêntica no sentido de vida própria só vem com esforço. Diz Ortega y Gasset em Ensimismamiento y Alteración: "me importa subrayar esto para aquellos de entre ustedes que se ocupam de Filosofia no son dones hechos al hombre. Nada que sea substantivo ha sido regalado al hombre. Todo tien que hacérlo el" ${ }^{13}$. Isso significa que, para nosso filósofo, vida autêntica depende de esforço e dedicação, ela não chega naturalmente.

$\mathrm{O}$ esforço humano na procura pela autenticidade se associa ao reconhecimento de que a vida possui um lado dramático. Em um trecho antológico Ortega y Gasset comenta a possibilidade de sobrevir a inautenticidade quando não há esforço para enfrentar as dificuldades presentes na circunstância. Ele escreve: "el hombre no es nunca seguramente hombre, sino que ser hombre significa precisamente, estar siempre a punto de no serlo, ser vivente problema, absoluta y azarosa aventura o, como yo suelo decir: ser, por esencia, drama. (...) Mientras el tigre no puede dejar de ser tigre, no puede destigrarse, el hombre en vive en riesgo permanente de deshumanizarse" 14

Dizer que a vida está cheia de drama significa reconhecer-lhe os riscos e ameaças como característico. O que o filósofo avalia é que o perigo é parte da vida, ele não é acessório. Comentou o fato em seu livro Viver é perigoso Gilberto Kujawski, um dos mais sutis comentadores brasileiros de Ortega. Ele diz viver é perigoso porque o perigo é parte integrante da vida mesma : "A vida é constitutivamente perigo porque viver é dirigir-se ao futuro e este paira em nosso caminho como horizonte de total incerteza e insegurança, eclosão de plenitude ou abismo de aniquilamento" ${ }^{\prime 15}$.

É assim que autenticidade, drama, risco se associam no pensamento orteguiano como se nota no comentário que ele tece a Nietzsche em Ensimismamiento y Alteración: "Vivid en peligro. Y este revela que Nietzsche, a pesar de su genialidad, ignoraba que la sustancia misma de nuestra vida es

\footnotetext{
${ }^{12}$ ARAUJO, Luis de Araújo. Sentido existencial de Filosofia. Rés-Editora, Porto, s.d., p. 66 - 67.

13 ORTEGA Y GASSET, José. Ensimismamiento y Alteración. Obras Completas. v. V, 2. reimpresión, Alianza, Madrid, 1994, p. 301.

${ }^{14}$ Ibidem, , p. 305.

${ }^{15}$ KUJAWSKI, Gilberto de Mello. Viver é perigoso. GDR, São Paulo, 1986, p. 3.
} 
peligro y que, por tanto, resulta un poco afectado y superfetatorio proponemos como algo nuevo, añadido y original que lo busquemos y lo coleccionemos ${ }^{16}$.

Todo empenho do ensimesmamento se ancora na cultura e na técnica que facilita o mergulho íntimo, o estar em si depende do controle que o homem tem da natureza. O desafio, é, portanto, valer-se da técnica para facilitar o mergulho íntimo e não perder-se nela e na rotina, deixando de ensimesmar-se. Trata-se de possibilidade que surgiu quando o homem desenvolveu a capacidade de pensar.

Pensar é fundamental para atuar no mundo de maneira autêntica, pois não basta responder às exigências quotidianas, é preciso realizar o projeto vital ou atuar conforme o núcleo íntimo do ser, esclarece o filósofo: "La acción es actuar sobre el contorno de las cosas materiales o de los otros hombres, conforme a un plan preconcebido en una previa contemplación o pensamiento" ${ }^{17}$.

\section{Ortega y Gasset: Autenticidade como vencer a circunstância}

No item anterior vimos como Ortega y Gasset estava próximo do que diziam destacados fenomenólogos sobre o problema da autenticidade. Agora vamos adiante. Uma vida autêntica não se realiza como fidelidade ao núcleo íntimo se ela não significar vencer a circunstância, pensava Ortega y Gasset. Circunstância, o que é isto?

Para entender como o filósofo concebe circunstância é necessário recordar o núcleo central da sua filosofia. Ao falar da vida humana caracterizou-a numa das passagens mais importantes das Meditaciones del Quijote do seguinte modo: "yo soy yo y mi circunstancia y si não salvo a ella, não salvo yo" ${ }^{18}$. Circunstância é, portanto, parte do que sou, mas é mais do que o eu. Eis como a questão pode ser resumida: "Circunstância não se confunde com o eu ou com a vida. Minha vida não se faz fora da circunstância, mas ela pode ir além de mim" ${ }^{19}$. Com a noção de circunstância Ortega y Gasset inicialmente se referia a todo contorno exterior ao sujeito, mas na fase final de seu pensamento denominou circunstância a tudo o que envolve o eu, incluído o corpo, o aparelho psíquico e a história de cada sujeito. Em Vejamen del orador escreveu que há níveis de circunstância uns mais

\footnotetext{
${ }^{16}$ ORTEGA Y GASSET, José. Ensimismamiento y Alteración. Obras Completas. v. V, Alianza, Madrid, 1994, p. 307.

${ }^{17}$ Ibidem, p. 308.

${ }^{18}$ ORTEGA Y GASSET, José. Meditaciones del Quijote. Obras Completas. v. I, Alianza, Madrid: 1997 , p. 69.

${ }^{19}$ CARVALHO, José Mauricio de. Introdução à Filosofia da Razão Vital de Ortega y Gasset. Cefil, Londrina, 2002 p. 70.
} 
amplos que outros ou "toda circunstancia está engajada en otra mas amplia"20.

A noção de autenticidade, na formulação orteguiana, indica que a fidelidade a si mesmo, entendida como um compromisso consigo mesmo, também precisa considerar o que na circunstância o impede de realizá-lo, por que circunstância e consciência do eu não se dissociam. Vida, por sua vez, foi definida na obra $E n$ torno a Galileo como o que fazer, como escolha entre as possibilidades que se apresentam na circunstância. Eis como o disse: "El hombre no puede dar un solo paso sin antecipar, com más o menos claridad, todo su porvenir, lo que va a ser; se entiende, lo que ha decidido ser en toda su vida" ${ }^{21}$.

\section{A autenticidade como enfrentamento das crises}

Pensar o significado de uma vida autêntica no contexto do raciovitalismo orteguiano obriga a considerar as crises pelas quais passam as sociedades e, no interior delas, as dificuldades dos indivíduos humanos. Ao pensar a autenticidade como problema, o filósofo se dá conta que as adversidades da vida muitas vezes se devem à crises da cultura. E, durante os tempos modernos, muitos problemas surgiram, como foi visto no item anterior por uma crise de cultura que nasceu ligada à noção de subjetividade. A ideia de subjetividade moderna não responde adequadamente à noção de circunstância com a qual nosso filósofo pensa a existência humana, como indicaremos, a seguir. E o que é a circunstância assim pensada por Ortega y Gasset? Eis como o diz Julián Marías: "La circunstancia es, por definición, lo que no soy yo, aquello con que me encuentro, el otro término de la dinámica coexistencia en que consiste la vida; pero, la inversa, solo existe como tal circunstancia en tanto en cuanto es para mí, en cuanto me circunda o rodea ${ }^{22}$.

Sabemos que para Ortega y Gasset cada homem é único e isso significa que cada um enfrentará os dilemas de sua vida particular e os da sua sociedade de modo diferente, porém todos de algum modo terão que se deparar com as crises da sociedade, pois não têm como viver fora do grupo. Contudo, o homem não pensa as dificuldades da sociedade por uma disposição natural para a reflexão, isto é, ele não se comporta naturalmente como intelectual ou, ao menos, nem todos o fazem. Esse entendimento inadequado da condição humana surge, na avaliação de Ortega, do modo grego de pensar. Os gregos supunha haver nas coisas um aspecto oculto à esperade ser revelado e esse elemento oculto é que

\footnotetext{
${ }^{20}$ ORTEGA Y GASSET, José. Vejamen del orador. Obras Completas. v. I, Alianza, Madrid, 1997, p. 563-564.

${ }^{21}$ ORTEGA Y GASSET, José. En torno a Galileo. Obras Completas. v. V, Alianza, Madrid, 1994, p.23.

${ }^{22}$ MARÍAS, Julián. Acerca de Ortega. Espasa Calpe, Madrid, 1991, p. 70.
} 
dava estabilidade ao real, conforme comenta Antoni Martín em seu artigo Verdad, conocimiento y realidad en Ortega:

Ortega combatió la que, en su opinión, era una de las ideas más tercas de la tradición intelectual de Occidente, aquella que considera al hombre como inclinado por naturaleza a conocer, y que permitió definirlo durante siglos como ser racional. Esta concepción del hombre habría ido acompañada por la tesis de que "las cosas, además del papel que representan en su relación inmediata con nosostros, tienen por sí mismas una segunda realidad oculta y más importante (...), una realidad latente a la cual llamamos su ser"23.

Como Ortega y Gasset pensa o mundo se ele evita esse modo grego de pensar? Ele o explica na lição 7 intitulada La verdad como coincidencia del hombre consigo mismo do livro Entorno a Galileo. Ali esclarece que o homem não procura naturalmente uma resposta racional para os problemas, mas o faz por uma razão muito necessária, isto é, para se sentir seguro na existência. Eis o que diz sobre o homem: "posse un sistema de convicciones auténticas, firmes - esto es, um mundo transparente ante si. Recuerdese que en nuestra terminologia mundo significa el conjunto de soluciones que el hombre halla para los problemas que su circunstancia le plantea" ${ }^{24}$.

O livro En torno a Galileo é um dos mais importantes de Ortega y Gasset e desenvolve a ideia de uma razão histórica contraposta à noção de razão pura e prática concebidas pela filosofia moderna. Sua crítica ao racionalismo moderno não foi elaborada em nome do irracionalismo, mas de uma outra forma de razão: histórica e vital. O texto foi elaborado em 1933 como curso ministrado na Universidad Central, embora como livro só tenha aparecido em 1942. Nele o filósofo desenvolve a tese de que o homem transita de uma crença a outra e que nos períodos de transição mergulha em tempos de crise. Essa análise revela que o problema da autenticidade vai além da fidelidade a si mesmo ou precisa incluir outro aspecto. E que aspecto é esse? A realidade social das diversas gerações e das crenças que nelas estão presentes. E por que surge essa atenção à realidade histórica dos grupos? O ano de 1933, quando Ortega ministra seu curso, fecha o ciclo iniciado em 1927, quando o filósofo passa a pensar a vida humana no tempo. Isso ocorre na esteira de sua leitura de Ser e Tiempo de Martin Heidegger. Conforme assinala Jaime de Salas na resenha que elaborou do livro Forme della ragione storica. La filosofia de Ortega y Gasset como filosofia europea, os conceitos elaborados no período, isto é, de 1927 até 1933, são fundamentais para a etapa final do pensamento orteguiano, ocasião em que ele desenvolve a tese da

\footnotetext{
${ }^{23}$ MARTÍN, Antoni Defez i. "Verdad, conocimiento y realidad en Ortega", en Revista de Estudios Orteguianos, n 6, Madrid, 2003, pp. 119-132.

${ }^{24}$ ORTEGA Y GASSET, José. En torno a Galileo. Obras Completas. v. V, Alianza, Madrid, 1994, p. 81 .
} 
razão histórica. Podemos dizer que a leitura do livro de Heidegger serve como elemento inaugural de uma nova fase de sua meditação. Salas comentou: "Se puede compreender el trabajo posterior como aplicación de estos conceptos a la propria circunstancia histórica"25. En torno a Galileo é essencial para compreender a autenticidade como compromisso íntimo, mas também como vivência de crenças que sustentam o indivíduo na existência.

O que Ortega y Gasset pretende na obra é deixar de lado uma razão teórica que se encontra desconectada da vida e de sua realidade. E qual o problema de uma razão pura e afastada da realidade social? Ela atua contra a vida porque estabelece regras ou ideais que acabam por asfixiá-la. A forma de evitar que isso ocorra é abandonar tanto a objetividade idealista dos modernos, quanto o realismo metafísico dos antigos e fixar a atenção na vida mesma, naquela que é experimentada na primeira pessoa. Essa vida é circunstancial e também histórica e social. As formulações teóricas antiga e moderna estão distanciadas do viver mesmo assim concebido. A razão orteguiana é uma função do ato de viver. O grande limite das duas perspectivas metafísicas tanto a concebida pelos modernos quanto aquela que eles criticavam é a formalização do ato intelectivo, perdendo de vista seu caráter experiencial. No capítulo que examinou a relação entre conhecimento filosófico e razão vital no livro A razão vital e histórica em Ortega y Gasset, Claudino Piletti esclarece bem o propósito orteguiano ao conceber essa forma de razão, superar o pensamento formalista: "Neste sentido a obra orteguiana é uma reivindicação constante contra tal equívoco. Ortega vislumbra claramente a insuficiência do pensamento formalista e critica os diferentes sistemas por esquecerem a dimensão vital e histórica da situação integral" 26 .

O pensamento formalista que Ortega rejeita é aquele pensado fora da circunstância, expressão da subjetividade moderna iniciada por René Descartes e que atingiu o ponto maior na filosofia crítica de Emanuel Kant. Assim, Ortega y Gasset não rejeita a razão, mas o racionalismo moderno e os movimentos que ela inspirou. No criticismo kantiano, por exemplo, que tenta fazer uma síntese entre racionalismo e empirismo, temos uma razão estruturada num esquema transcendental que é universalmente compartilhado por todos os homens, independente do tempo e das experiências vividas. É essa razão pura que nosso filósofo não aceita. Howard Gaygill assim explica o significado da razão pura construída no criticismo kantiano: "A razão, (...), não está vinculada às condições

\footnotetext{
${ }^{25}$ SALA, Javier San Martín. Ortega como fenomenólogo. In: AMOEDO, M., BARROS DIAS, J.M. e DELGADO, A. S. José Ortega y Gasset. leituras críticas, no cinquentenário da morte do autor. Edição da Universidade, Évora, 2007. p. 282.

${ }^{26}$ PILETTI, Claudino. A razão vital e histórica em Ortega y Gasset. Instituto Estadual do Livro, Porto Alegre, 1968, p. 22.
} 
de uma experiência possível mas 'refere-se à totalidade absoluta na síntese das condições e só termina no absolutamente incondicionado, ou seja, incondicionado em todos os sentidos" ${ }^{27}$. E essa razão de sentido universal que parece a Kant um esquema racional universalmente distribuído a todos os homens, em todos os tempos, porque funciona mediando a relação entre os conceitos e a intuição sensível. Eis como Gaygill explica o esquema transcendental concebido por Kant:

Esquema e esquematismo desempenham um importante, mas controvertido papel na Crítica da Razão Pura. São examinados no primeiro capítulo da Doutrina transcendental da faculdade de julgar onde se afirma constituírem um terceiro termo (CRP) que medeia entre conceitos tão diferentes e heterogênos e a intuição. Desempenham um papel necessário na doutrina da faculdade de julgar, porquanto permitem a aplicação das categorias às aparências ${ }^{28}$

Ao comentar recente reedição crítica do livro En torno a Galileo, realizada em 2012, Javier Zamora Bonilla destaca a importância da obra no contexto da filosofia orteguiana e comenta sua gênese do seguinte modo: "En torno a Galileo es uno de los mejores libros de Ortega y Gasset y también uno de los más importantes publicados en España y en el mundo en el passado siglo XX. Es, además, un libro tipicamente orteguiano: nace como un curso en la catedra Valecilla de la Universidad Central, impartido en 1933 y titulado Sobre la época de Galileo (1550-1650)"29.

Voltando ao que disse Ortega no capítulo 7 de En torno a Galileo, encontramos um homem que não vive separado da circunstância, sendo nela lançado para aí viver, mesmo quando não é capaz de entender bem como se passam as coisas. E assim perdido entre o que se passa, ele acaba se afastando de si mesmo, distanciando-se do que verdadeiramente é: "Al vivir he sido lanzado a la circunstancia, al enjambre caótico y punzante de las cosas: en ellas me pierdo, pero me pierdo no porque sean muchas y difíciles e ingratas, sino porque ellas me sacan de mí, me hacen otro (alter), me alteran y me confunden y mi pierdo de vista a mí mismo"30.

$\mathrm{Na}$ circunstância social em que vive, o homem encontra-se envolvido por crenças. Elas são denominadas autênticas por Ortega y Gasset porque o governam, o dirigem, mesmo que ele não se ocupe em conhecê-las. E o

${ }^{27}$ CAYGILL, Howard. Dicionário Kant. Zahar, Rio de Janeiro, 2000, p. 272.

${ }^{28}$ Ibidem, p. 126.

${ }^{29}$ BONILLA, Javier Zamora. "Meditación de la crisis", en Revista de Estudios Orteguianos, n 26, Madrid, 2013, pp. 197-200.

${ }^{30}$ ORTEGA Y GASSET, José. En torno a Galileo. Obras Completas. v. V, Alianza, Madrid, 1994, p. 86. 
indivíduo não se preocupa porque crenças são problemas em que ele se encontra vitalmente mergulhado e não desafios intelectuais à espera de análise. Essa conclusão era evidente nos dias em que vivia o filósofo, pois, ele assim observava, seus contemporâneos não se ocupavam de compreender as crenças em que viviam. E isso ocorria porque o homem do século XX se tornara parte da massa, afastou-se do compromisso para consigo de viver singularmente, de encontrar-se. E esse fato ocorre todas as vezes na história de uma sociedade em que ser parte do grupo se sobrepõe ao desejo de viver exemplarmente e de modo singular. É o que o filósofo esclarece no capítulo 6 de En torno a Galileo:

Toda cultura o grande etapa de ella termina por la socialización del hombre y, viveversa, la socialización arranca al hombre de su vida en soledad que es auténtica. Notese que la socialización del hombre, su absorción por el yo social aparece al extremo de la evolución cultural, pero también antes de la cultura. El hombre primitivo es un hombre socializado, sin individualidad ${ }^{31}$

Assim tocamos em algo essencial para uma vida singularamente humana, o homem só consegue ser autêntico se for fiel a si e só o é se permanece mergulhado em si, isto é, afastado do grupo ou do que, no ato de viver, o mantém voltado para fora. Ele necessita saber em que é singular e distinto de toda a gente para se perceber autêntico. Autenticidade é o nome que Ortega y Gasset dá ao respeito à singularidade existencial, reconhecida e vivida na fidelidade ao que se é. E para ser singular é preciso pensar sobre a própria particularidade, reconhecêla.

O homem sempre corre o risco de perder suas autênticas crenças e isso é o que ocorre quando ele não está em si e mergulha na crise. O conceito de crise é fundamental em todo o livro de Ortega e é necessário para entendermos como é a vida que ocorre no tempo. A vida humana é histórica ou temporal, o que é o mesmo. E não entendemos vida histórica sem crise. E o que é crise? Crise é o que se passa no íntimo de cada um quando algo acontece e muda uma parte do seu mundo. A crise é ainda mais intensa quando muda o próprio mundo e nele tudo o que o indivíduo tem por seguro. Nesses momentos de mudanças profundas é como se nos fosse tirado o chão sob nossos pés. O filósofo explica as duas formas como a crise se manifesta do seguinte modo: "Repasando lo dicho ne lecciones anteriores, nos encontramos com dos formas de cambio vital histórico: 1. Cuando cambia algo en nuestro mundo. 2. Cuando cambia el mundo" ${ }^{32}$.

\footnotetext{
${ }^{31}$ Ibidem, p. 78.

${ }^{32}$ ORTEGA Y GASSET, José. En torno a Galileo. Obras Completas. v. V, 2. reimpresión, Alianza, Madrid, 1994, p. 69.
} 
Nos momentos de crise o homem perde a segurança e, por consequência, ele não tem rumo na vida. Então ele se move para um e outro lado, mas não está seguro de qual caminho seguir, pois não tem convencimento dos seus movimentos. E o resultado dessas idas e vindas sem rumo certo é a inautenticidade que acomete não só os indivíduos, mas gerações inteiras. A observação abaixo mostra que para o filósofo não só as pessoas perdem a autenticidade, mas também sociedades inteiras podem perdê-la durante certo tempo. Eis como o disse:

En las épocas de crisis son muy frecuentes las posiciones falsas, fingidas. Generaciones enteras se falsifican a si mismas, quiero decir, se embalan en estilos artísticos, en doctrinas, en movimientos políticos que son insinceros y que llevan el hueco de auténticas convicciones. Cuando se acercan a los cuarenta años esas generaciones quedan anuladas, porque a esa edad no se puede ya vivir de ficciones: hay que estar en la verdad $^{33}$.

A citação acima explicita outro aspecto da autenticidade: a convicção. $\mathrm{O}$ homem não pode viver sem convicção sobre si mesmo e sobre o que é o mundo onde vive. Quando ele perde a crença em si e no mundo mergulha no que o filósofo denomina conviç̧ão negativa. Nessas ocasiões ele não só não sabe o que é certo, mas nada lhe parece merecer seu entusiasmo e alegria. Ele fica perdido e não se compromete com nada de verdade. E a vida assim tocada na superficialidade parece-lhe inconsistente, indigna de ser vivida. Uma vida sem convicção é uma vida inautentica e inautenticidade culmina na angústia, tema de muitas considerações na filosofia contemporânea. Sobre ela, Martin Heidegger escreveu páginas memoráveis e afirmou a condição singular do homem, expressando-se na aceitação da morte como possibilidade irrecusável e insuperável do homem. Essa condição significa tornar-se consciente da impossibilidade da existência como tal. Ortega y Gasset enxerga a angústia como vazio que brota da falta de convicção, mas avalia, diversamente de Heidegger, que como o homem não oconsegue viver neste estado, então sua angustia o orienta para construir novas convicções. Contudo, enquanto ele está mergulhado na angústia fica perdido e desesperado. Nessas ocasiões ocupa-se de várias coisas, mas nenhuma delas lhe satisfaz verdadeiramente, conforme explica o filósofo:

El hombre sentirá escéptica frialdad o bien angustia al sentirse perdido o bien desesperación y hará muchas cosas de aspecto heroico que, en verdad, no proceden de efectivo heroísmo, sino que son hechas a la desesperada, o bien sentirá furia, frenesí, apetito de venganza por el vacío de su vida que le incita a gozar brutalmente,

\footnotetext{
${ }^{33}$ Ibidem, p. 70.
} 
cinicamente de lo que encuentra a su paso - carne, lujo, poderio. La vida toma sabor $\operatorname{amargo}^{34}$

Para superar os períodos de crise e a angústia que neles brota, o homem procura converter suas ideias em novas crenças que lhe permitam sentir-se seguro no novo mundo que está surgindo. Assim é porque, para nosso filósofo, não é possível viver sem crença. E como são os dias que vivemos? Eles são caracterizados pelo surgimento da nova família, pela presença constante da mulher no mercado de trabalho ocupada com a dupla jornada, aumento da ausência dos pais nos lares, redução do tempo de convivência entre pais e filhos, vida sexual livre, maior desejo de consumo de bens, relações afetivas passageiras, popularização do uso das drogas, tudo confluindo para o gozo efêmero e ansioso. Essas características de nossos dias mostram que o momento de crise identificada pelos filósofos da escola existencial, no século passado, ainda não terminou e o homem ainda não conseguiu atingir um novo momento de estabilidade, ou uma nova era de ouro. Essa situação mantém atual as análises de Ortega sobre as dificuldades existentes na sociedade ocidental. É o que se comenta em Totalitarismo e ética em Ortega y Gasset quando pudemos avaliar as dificuldades dos nossos dias: "Este não é um fenômeno de hoje, ocorre desde o início do século XX quando a abundância de bens associou-se à falta de compromisso com os deveres na raiz da crise identificada por Ortega y Gasset no novo perfil das massas" ${ }^{35}$.

A análise orteguiana da vida autêntica dá importância a estar em si como estratégia para enfrentar as crises. E os grandes problemas do século passado surgiram porque o homem despreocupou-se de estar consigo mergulhado na solidão criadora que leva à autenticidade. E renunciando a estar consigo desejou ser como todo mundo, não como este ou aquele homem exemplar, o que não seria mal, mas esperava ser como todos ou como ninguém. Para Ortega y Gasset, ser como toda a gente, tornar-se parte da massa que não é ninguém e não pode ser responsabilizada por seus atos e escolhas é uma forma de vida inautêntica. Ortega y Gasset considera, portanto, que a vida autêntica é experimentada na intimidade, na solidão, no espaço interior que se contrapõe à vida comum encontrada na sociedade. Eis como o pensador considera a vida autêntica no livro En torno a Galileo: "Lo que decimos es simplesmente que la vida tiene realidad - no bondad ou meritoriedad, sino pura y simples realidade en la medida

\footnotetext{
${ }^{34}$ Ibidem, p. 71.

${ }^{35}$ CARVALHO, José Maurício de e BESSA, Vanessa da Costa. Totalitarismo e ética em Ortega y Gasset en CARVALHO, José Maurício de. Poder e moralidade; o totalitarismo e outras experiências antiliberais na modernidade, Annablume, São Paulo, 2012, p. 124.
} 
en que es auténtica, en que cada hombre siente, piensa, y hace lo que él y solo él, individualissimamente tien que sentir, pensar y hacer" ${ }^{36}$.

A vida autêntica é aquela que o homem assume e experimenta na primeira pessoa não porque os outros agem e se comportam de um modo tal, mas porque ele a experimenta como só ele pode fazê-lo. E como a vida assim vivida tem dias e horas contadas, o tempo perdido em ser parecido com outros ou em seguir um projeto alheio é um vazio de autenticidade. Assim, a vida autêntica é aquela vivida na solidão, exige ensimesmamento e a fidelidade ao núcleo íntimo.

Quando nos momentos de crise o homem se encontra perdido, ele é desafiado a mergulhar em si para aí descobrir a saída para a inautenticidade. É isso o que se espera que ocorra todas as vezes em que a cultura mergulha em crise, que o homem voltando a si descubra boas razões para viver ou que consolide novas crenças nas quais possa se instalar. Quando há sucesso no estabelecimento de uma nova crença surgem os períodos clássicos ou séculos de ouro, onde a vida autêntica espanta a sensação de crise. Nesses dias o homem se entrega apaixonado aos desafios que encontra e realiza grandes coisas.

\section{A autenticidade como superação da crise contemporânea}

E aí temos uma questão fundamental, se o indivíduo é o eu e a circunstância, ele pode perder a autenticidade se não vence na circunstância o que lhe impede de realizar o que ele é. E ao pensar o seu tempo, Ortega y Gasset identificou uma crise que inicialmente pensou ser espanhola, mas que concluiu tratar-se de fenômeno amplo, de uma crise de civilização. Essa crise, como indicado em $O$ século XX em El Espectador de Ortega y Gasset, a crise como desvio moral nasce da inautenticidade:

A característica fundamental da crise do século XX era uma atitude comum que, segundo Ortega y Gasset, marcava a massa e a minoria da sociedade. (...). O que ele observa é que no século $\mathrm{XX}$, as minorias mais bem educadas nos diversos campos culturais não assumiam a tarefa de dirigir a sociedade, não respondiam aos novos desafios que a vida apresenta, cultivavam um saber muito especializado e ignoravam quase todos os assuntos $^{37}$

O que está contido na citação acima é que vencer a crise de civilização exigia a superação do tipo de homem encontrado naquele momento histórico. Vamos mostrar, a seguir, como Ortega y Gasset espera superar a crise de civilização

\footnotetext{
${ }^{36}$ ORTEGA Y GASSET, José. En torno a Galileo. Obras Completas. v. V, Alianza, Madrid, 1994, p. 75.

CARVALHO, José Maurício de. O século XX em El Espectador de Ortega y Gasset, a crise como desvio moral en Argumentos. 2 (4), Fortaleza, 2010, p. 15.
} 
alterando a formação do sujeito para permitir-lhe buscar a autenticidade. Primeiro precisamos caracterizar esse homem massa que precisava de outra formação. E quem era o homem massa? Alguém que não tinha compromisso de ser autêntico. Esse sujeito não responde às necessidades de seu tempo, é uma espécie de novo bárbaro. Em síntese feita em Ética e Direito no discurso político de Ortega y Gasset encontra-se rápida caracterização desse novo bárbaro: "O novo bárbaro que emergia no horizonte histórico possuía características que o diferenciavam do antigo: senhorio satisfeito, jovem mimado e bárbaro especialista" ${ }^{38}$.

Nos capítulos finais da primeira parte de La rebelión de las masas, o filósofo esclarece como é a vida desse novo bárbaro dizendo que ele parece um senhorio satisfeito. E o que é ser tal? No capítulo XI do livro Ortega y Gasset explica que o homem massa está satisfeito com o que é, acredita que viver é fácil, não percebe que a vida possui limitações trágicas e riscos. Acredita, do modo infantil, que seus problemas serão resolvidos com o que ele herdou das antigas gerações. Está feliz com o que sabe, não julga que deva se esforçar para mudar o mundo e sua vida, mas está convencido de poder participar do universo social e lhe dar direção. Diz o filósofo: "Este contentamiento consigo le lleva a cerrarse para toda instancia exterior, a no escuchar, a no poner tela de juício sus opiniones y a no contar com los demás. Su sensación íntima de dominio le incita constantemente a exerjer predominio"39.

E qual o resultado desta satisfação pouco crítica? O de se comportar como menino mimado que não aceita ser contrariado. Eis como o explica: "Este repertorio de facciones nos hizo pensar em ciertos modos deficientes de ser hombre, como el niño mimado y el primitivo rebelde, es decir, el bárbaro" ${ }^{40}$.

O homem massa encontra-se deslumbrado com os resultados da tecnologia, está satisfeito com tudo quanto tem à sua disposição, mas não se dá conta do quanto de sofrimento, riscos e angústias estiveram associadas ao esforço de as produzir. Ele é inconsciente do esforço e dos perigos da vida, o que falseia sua percepção do assunto e suas atitudes. Ele se torna um risco para as futuras gerações, por que não assume o compromisso de fazer melhor a herança que recebeu. O fato leva Ortega y Gasset a considerar que quando o homem massa se torna figura central do espaço coletivo "é preciso dar la voz de alarma y anunciar que la vida se halla amenazada de degeneración, es decir, de relativa morte" ${ }^{41}$.

\footnotetext{
38 CARVALHO, José Maurício de e BESSA, Vanessa da Costa. Ética e direito no discurso político de Ortega y Gasset, en Éthic@.nº 9 (17), Florianópolis, 2012, pp. 102

${ }^{39}$ ORTEGA Y GASSET, José. La rebelión de las masas. Obras Completas. v. IV, Alianza, Madrid, 1994, p. 207.

${ }^{40}$ Ibidem, p. 207.

${ }^{41}$ Ibidem, p. 210.
} 
A vida do homem massa é inautêntica, por que ela está afastada do risco e a vida é risco como dito anteriormente. Uma sociedade de homens massa pensa como criança.

A infantilidade do homem massa leva-o a viver em sociedade como se vive em casa. Ele acredita que pode se portar na rua como em casa e "el que cre que nada es fatal, irremediable e irrevocable" ${ }^{42}$. Ortega y Gasset esclarece então porque o senhorio satisfeito é um homem contraditório: "el señorito satisfecho se caracteriza por saber que ciertas coisas no pueden ser y, sin embargo, (...) fingir con sus actos y palabras la convicción contraria"43. Esta atitude alimenta uma crise de civilização onde se adota posições e se defendem coisas que no íntimo se sabe serem falsas. O homem massa age como o cínico no helenismo que apregoava o niilismo, mas sabia que a civilização estava ali para protegê-lo da barbarie e que ela não se desfaria com suas pregações. E pergunta: "Qué haría el cínico en un pueblo salvaje donde todos, naturalmente y en serio, hacen lo que él, en farsa, considera como su papel personal?" 44 .

A outra característica do homem massa é o de ser um especialista, nascido da exigência da especialização imposta pela ciência moderna. Essa exigência o converte em homem massa, quer dizer, faz dele um primitivo, um bárbaro moderno. E por que ele é bárbaro? Porque conhece muito de um pequeno campo do conhecimento e é ignorante de todo o resto. Dito de outro modo: "Ele aprendeu uma técnica sofisticada ou uma profissão exigente, mas é ignorante de quase todos os outros assuntos" 45 .

Há algo curioso no comportamento desse novo bárbaro. Além de ignorante é prepotente porque se comporta como sábio em assuntos que desconhece. E a prepotência faz dele um insubordinado que não reconhece "instancias superiores" $^{46}$ no sentido de que despreza conhecimentos e talentos maiores que os seus. A autenticidade só poderá ser recuperada por uma nova geração que enfrente a essência da vida de outra forma. Que recupere o que a vida possui de autêntico.

Fica claro, nas considerações de La rebelión de las masas, que só uma reforma na formação do homem europeu poderá levar à superação da inautenticidade da vida e da crise de civilização. Qual é o cerne do problema? A falta de sentido, a desorientação daquela geração que não enxerga os riscos da

\footnotetext{
${ }^{42}$ Ibidem, p. 211.

${ }^{43}$ Ibidem, p. 213.

${ }^{44}$ Ibidem, p. 214.

${ }^{45}$ CARVALHO, José Maurício de e BESSA, Vanessa da Costa. Totalitarismo e ética em Ortega y Gasset, en CARVALHO, José Maurício de. Poder e moralidade; o totalitarismo e outras experiências antiliberais na modernidade, Annablume, São Paulo, 2012, p. 121.

${ }^{46}$ Ibidem, p. 219.
} 
vida. Não é um problema restrito ao conteúdo da aprendizagem, como observa Cascalès: "el hombre se encuentra sen niente para hacer, sin programa de vida, desmotivado" 47 .

Em Misión de la universidad, outro trabalho de 1930, Ortega propõe a reforma da universidade como estratégia para enfrentar a inautenticidade daquele momento histórico. Ele apresenta um programa de formação do homem culto. Culto é quem aprende a ideia viva que alimenta as crenças de seu tempo. Esses elementos nem sempre são conscientes, mas contém aspectos que são. $\mathrm{O}$ conhecimento limitado aos saberes específicos da profissão é uma das razões do surgimento do homem massa. A formação universitária proposta por Ortega y Gasset era ampla e pretendia combater o fenômeno das massas. O assunto é assim proposto: "la enseñanza superior es primordialmente enseñanza de la cultura o transmisión a la nueva generación del sistema de ideias sobre el mundo y el hombre que llegó a madurez en la anterior" ${ }^{48}$.

Quando perde o caráter cultural a universidade deixa de ser essencialmente o que ela é e se torna inautêntica. É o que ocorre ao homem ou instituição quando, afastada de seu cerne, se torna falso. Diz Ortega y Gasset: "el pecado original radica en eso: no ser auténticamente lo que se é"49. O propósito de recuperar a autenticidade da universidade era para combater a inautenticidade do homem. E o que faz a universidade autêntica? Forma o homem culto, pois, diz o filósofo: "no hay remedio: para andar con acierto en la selva de la vida, hay que ser culto, hay que conocer su topografia, sus rutas o métodos, hay que tener una idea del espacio y del tiempo en que se vive, una cultura actual"50.

\section{Considerações finais}

As considerações de Ortega y Gasset sobre a autenticidade da vida nos colocam frente ao fato de que a vida humana não será o que pode ser, sem que cada qual seja responsável por sua criação. Até aí segue Ortega os representantes da fenomenologia existencial. No entanto, vida só se torna roteiro pessoal e cenário construído pelo sujeito quando ele é o artífice da superação do que no mundo o impede de viver autenticamente. É, portanto, Ortega y Gasset o arauto da

\footnotetext{
${ }^{47}$ CASCALÈS, Charles. L'humanisme d'Ortega y Gasset. Presses Universitaires de France, Paris, 1957, p. 153.

48 ORTEGA Y GASSET, José. Misión de la universidad. Obras Completas. v. IV, 2. reimpresión, Alianza, Madrid, 1994, p. 325.

${ }^{49}$ Ibidem, p. 327.

${ }^{50}$ Ibidem, p. 324.
} 
confiança numa vida com bom destino, mesmo nos momentos de crise e condições adversas.

Se vivemos num tempo de dificuldades ambientais e culturais em que ansiosamente se busca o prazer rápido e inconsequente, se vemos surgir um sujeito consumista e ansioso, muitas vezes pretendendo, de forma rápida e à margem das instituições solucionar suas dificuldades, se dogmas religiosos não são aceitos, se aumenta o consumo de drogas, se o trabalho fica limitado a aumentar o consumo, se a nova família é um desafio para as futuras gerações, listamos dificuldades para as quais a procura de autenticidade e as meditações de Ortega y Gasset ainda são importantes referências a retomar. 
